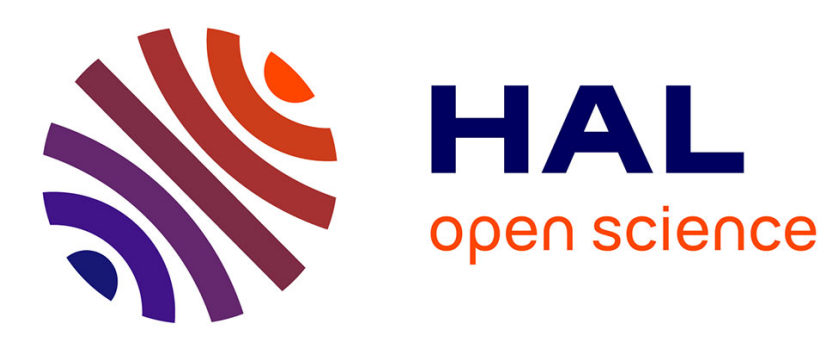

\title{
Fighting the Minotaur: Resistance to technological change in the Mediterranean sponge fishing industry, 1840-1922
}

\author{
Maia Fourt, Daniel Faget, Thierry Perez
}

\section{To cite this version:}

Maia Fourt, Daniel Faget, Thierry Perez. Fighting the Minotaur: Resistance to technological change in the Mediterranean sponge fishing industry, 1840-1922. International Journal of Maritime History, 2020, 32 (2), pp.337-353. 10.1177/0843871420920958 . hal-02932097

\section{HAL Id: hal-02932097 \\ https://hal-amu.archives-ouvertes.fr/hal-02932097}

Submitted on 4 Dec 2020

HAL is a multi-disciplinary open access archive for the deposit and dissemination of scientific research documents, whether they are published or not. The documents may come from teaching and research institutions in France or abroad, or from public or private research centers.
L'archive ouverte pluridisciplinaire HAL, est destinée au dépôt et à la diffusion de documents scientifiques de niveau recherche, publiés ou non, émanant des établissements d'enseignement et de recherche français ou étrangers, des laboratoires publics ou privés.

\section{(1) (1) $\$$}

Distributed under a Creative Commons Attribution - NonCommercial - NoDerivatives 44.0 


\title{
Fighting the Minotaur: resistance and transformation of the sponge fisherman society following the introduction of the hard-hat diving suit (1840-1922)
}

\author{
Fourt M. ${ }^{1}$, Faget $D .^{2}$, Pérez T. ${ }^{1}$ \\ ${ }^{1}$ Institut Méditerranéen de Biodiversité et d'Ecologie marine et continentale (IMBE), Aix \\ Marseille Université, CNRS, IRD, Avignon Université. Station Marine d'Endoume, Rue de la \\ Batterie des Lions, 13007 Marseille, France. \\ ${ }^{2}$ Laboratoire TELEMME, Aix-Marseille Université, CNRS, Maison Méditerranéenne des \\ Sciences de l'Homme (MMSH), 5, rue du Château de l'horloge, BP 647, 13094 Aix-en- \\ Provence, France.
}

Sponge fishing was first reported in Antiquity and has been practiced throughout the modern era on various islands of the Aegean Sea. The Dodecanese Archipelago has played an important role in this specialized fishery with some populations (Kalymniots, Symiots) being recognized since the eighteenth century for the exceptional capabilities of their skin-divers ${ }^{1}$.

During the first half of the nineteenth century, the Industrial Revolution and the increasing demand for sponges stimulated the dissemination throughout these islands of a new type of fishing gear, the "hard-hat" diving suit (Fig.1). By questioning the consequences of a technical upheaval in the sponge fishing fleet between 1840 and the immediate aftermath of the First World War, the proposed study will be structured by a triple interrogation. The first question relates to the circumstances surrounding the introduction of this new fishing equipment in the Dodecanese Islands. Who were the actors and networks that introduced this new technology, and how was it accepted by the local populations? The dissemination of the hardhat diving suit marked an important technological breakthrough in the organization of port societies and led to the industrialization of the Mediterranean sponge fishery. How did this development trigger the emergence of new capitalist structures in the ports of the Eastern Mediterranean Sea, and what consequences came into play on the social structures of Aegean Sea fishing fleets? This new equipment allowed longer forays underwater, but took a severe toll on the health of the crews. Can we estimate the consequences that this new gear had on human health, or quantify how it encouraged the development of new social norms that were to be formalized in the Dodecanese just before the First World War? 


\section{I- The introduction of a new technology in the Dodecanese}

\section{Commercial sponges and the Industrial Revolution}

The hard-hat diving suit, also called "the machine", appeared in the Aegean Sea for the first time in the mid-1850s, and was a technological response to the demand of a booming market. "The prodigious increase in the number of cars and horses and a new trend of indoor cleanliness have increased tenfold the need for sponges in Europe over the last twenty years...". In 1838, describing the popularity of sponges among the Western European countries, French Vice-Consul Rottier clearly designated two of the main uses of this natural resource in the $19^{\text {th }}$ century. The first use can be linked to the rise of an increasingly horse-drawn civilization which drew primarily on resources of the common sponge Hippospongia communis. This sponge was mainly harvested in the Gulf of Gabes and along the Libyan coast, whereas the different sponge species caught in the Dodecanese waters corresponded to the new standards of bodily hygiene. The amount of water available per capita in Paris increased from $7.5 \mathrm{~L}$ in 1840 to $114 \mathrm{~L}$ in 1870, and sponges gradually became common objects in working class households. A sign of the times, sponges were often represented in painted works too, such as in the Femme au tub by Pierre Bonnard in $1914^{2}$.

Distant though they were from the raging fad for shower-baths or the luxury of the first private bathrooms of Paris, London and Berlin, the fishing populations of the Dodecanese had to meet the western demand from the first half of the $19^{\text {th }}$ century. They experienced such an increase in activity between 1830 and 1860 that these decades helped to forge, in the insular collective consciousness, the memory of a golden age gone by. Describing the situation of fishermen more than 50 years later, Charles Flégel, founder of the International Society for the Protection of Sponge Fishermen, wrote in 1912 that they "lived happily when fishing was practiced with old methods", while the Symiot merchant Georges Eleftheris Georgas mentions in a 1926 memoir "an enviable prosperity [...] which lasted several centuries"3

Although based on an ideal representation of the past, these mentions are confirmed both by the rise of sponge prices and by the increase of the fleet. During his travels to Syria in 1852, the French orientalist Victor Langlois noted a sharp increase in the value of sponges due to a greater demand, while in the Dodecanese Archipelago, the prices of the common horny sponge tripled between 1852 and $1860^{4}$. 
Fishermen responded to the increasing demand by increasing the size of their fleets and by extending fishing zones towards the Libyan and Tunisian coasts. As early as 1840, the fishermen of the Southern Sporades, under Ottoman rule, expanded their areas of exploitation to the rich North African banks of Mandroucha, Derna and Benghazi. This general movement is confirmed by the increase in the number of boats mobilized for this fishery in the port of Pothia (Kalymnos), which rose from 200 vessels in 1854 to 370 in 1860. During the same period, the fishermen of the Dodecanese intensified their efforts by relying on traditional methods, among which skin diving was essential. But this ancient harvesting technique underwent significant change around 1840 with the appearance of the "scandalopetra" or "kambanellopetra", that is to say, the diving stone. This innovation was probably copied from the method used by pearl fishermen in the Red Sea, where a stone slab was tied to the boat with a rope. This enabled the diver to reach the sea bottom faster than previously, but also to communicate with the surface and to be hauled aboard very quickly at the end of the dive ${ }^{5}$.

In this context of sustained growth and mobilization in the eastern Mediterranean, the hard-hat diving suit made its appearance in the early 1860s.

\section{$\underline{\text { Players and resistance }}$}

The "hard-hat" diving suit was invented in the late eighteenth century and acquired its classic shape with a waterproof helmet and a complete garment between 1837 and 1855, following improvements made by the engineers Augustin Siebe and Joseph Martin Cabirol. Its widespread distribution throughout the Levantine Basin of the Mediterranean began in Syria in 1855 when the first "machine" was introduced by a diver working for the Parisian trading house Coulombel and Devismes ${ }^{6}$.

It would appear that the first diving suit to reach the Dodecanese Islands was introduced by a diver by the name of Fotio Mastoriadis from the island of Symi. After working in Singapore for an English refloating company, he returned to his island with the invaluable gear in early 1863. The equipment is then thought to have spread the following year throughout the Dodecanese, to Kalymnos, Chalki and Castellorizo for example, permitting unexpectedly good yields, before going on to conquer the Greek fishing centres of Hydra, Aegina, Kranidi and Ermione ${ }^{7}$.

Sources detailing the chronology of this arrival are rare, but those that do exist not only bring to light the role of European traders and their local representatives in the dissemination 
of this new technology, but also describe the resistance generated by this innovation. The Southern Sporades experienced a year of turmoil in 1865, at which time several diving suits were already being used. Indeed, while the fishermen of Symi were mourning the victims of the first diving accidents during a dramatic summer campaign, 11 vessels suffered extensive damage during a severe storm that occurred on $28^{\text {th }}$ August 1865 off the African coast. To add insult to injury during this disastrous season, the ship owners claimed that the disaster could only be explained by fate or by the carelessness of the captains ${ }^{8}$.

Following this, an unprecedented movement of rebellion took place among the Mediterranean fishing populations of the Dodecanese. With the appearance of maritime Luddites, this uprising resulted in repeated violent destruction of hard-hat diving suits, while their promoters, who were seen as representing the interests of international trade, were even threatened with death. The revolt was initiated by the widows of the Symi fishermen. In 1865, these Symiot women symbolically voted to abolish the use of the hard-hat diving suit, and the Kalymniots were not far behind. On October 8, 1865, the island's sponge fishermen assembled in the port of Pothia and, backed by the town council and thus feeling a certain impunity, broke into the home of Zérounis, who represented the interests of the French trading house Silvain Milles et Cie on the island. The protesters destroyed the diving suit which was stored there, and carried the broken pieces and the debris of the helmet and air-pipe like symbolic trophies across the island ${ }^{9}$. 


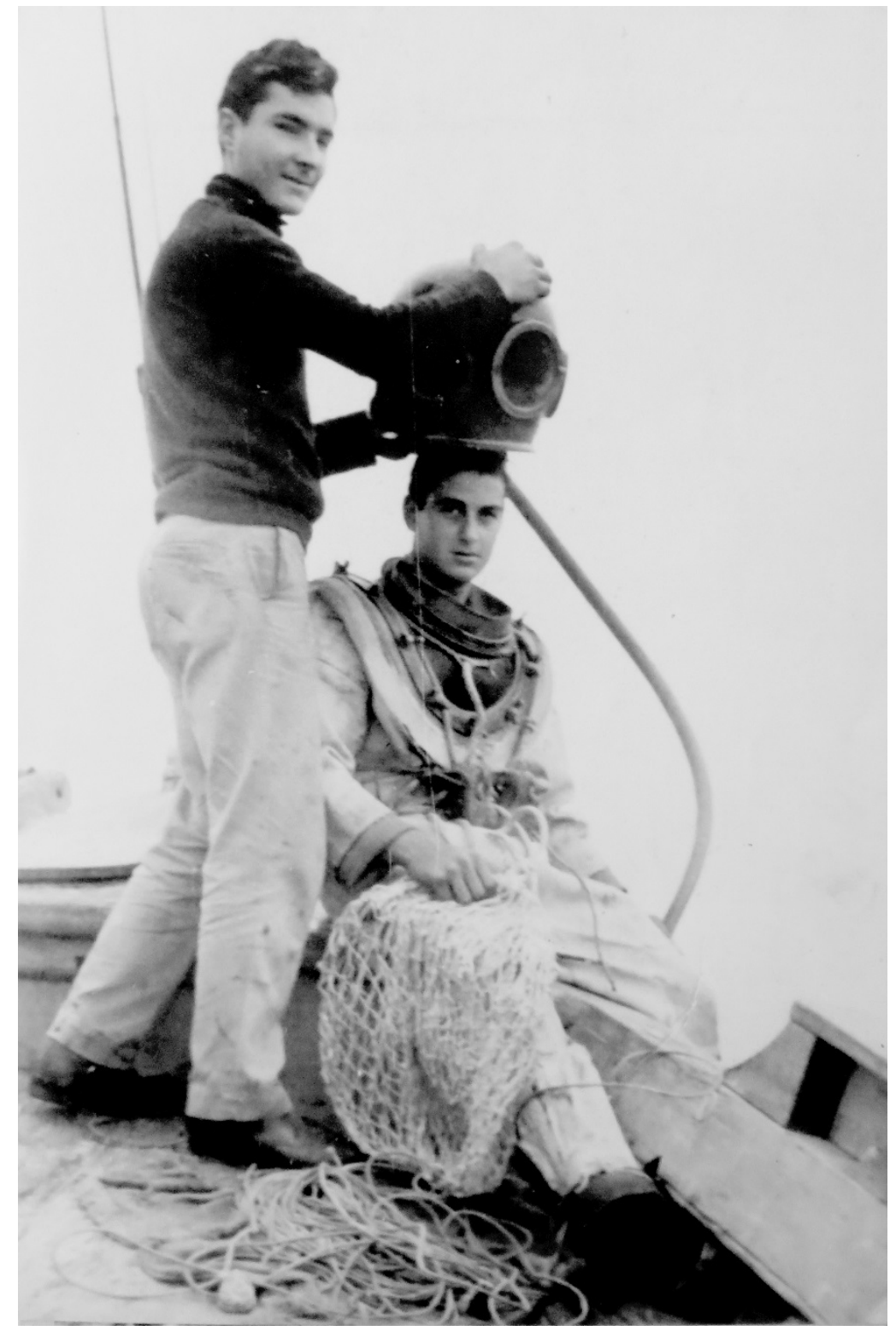

Figure 1: Sponge fisherman in a hard-hat diving suit. Photograph from the Stratis Liadellis ( $\Sigma \tau \rho \alpha \tau \iota \varsigma \Lambda \imath \alpha \delta \varepsilon \lambda \lambda \eta \varsigma)$ private collection, Lemnos Island, Greece (1955-1960).

French interests were not the only ones to suffer from this organized violence, and during 1866, insurgencies against the hard hat diving suit multiplied. Maïlis, the representative of an Italian trading company established in Kalymnos, paid the price on November 5 1866, during the visit of the Ottoman governor of Rhodes to the island. The previous month, 4 or 5 suits belonging to Russian or Greek traders had also been destroyed in Symi ${ }^{10}$.

The rebellion cannot thus be reduced to a hypothetical anti-French movement, triggered by international competition, as evoked by Pierre Aublé who was in charge of the interests of the Silvain Milles trading house in Rhodes. The revolt indeed took the form of widespread 
opposition to foreign investors. An illustration can be seen in the declaration made by the Kalymniots, who proclaimed in the summer of 1866 that "in the future, they would no longer allow the use of hard hat diving suits to feed the European market" ${ }^{11}$.

The question of manipulation of the skin divers by the local notables, the traditional financiers of the fishing campaigns, can obviously be raised. This hypothesis was put forward as early as 1866 by British Vice-Consul Biliotti in Rhodes. The following year, Aublé said in reference to the skin divers that "they are all under the yoke of 4 or 5 individuals pretexting to help them to earn money whereas they have themselves made big fortunes on their misery". Indeed, before each fishing season, the local capitalists advanced funds which could return $100 \%$ interest to investors. These financiers may appear to be the chief parties responsible for the crisis. However, this alone does not explain the massive opposition of the port populations to the hard-hat diving suits. Fisher families enjoyed relative autonomy in the organization of their fishing campaigns, even when in debt. However, their anxiety faced with the introduction of a much more powerful "machine” played out fully at that time. The acquisition of hard-hat equipment was definitely a class-oriented pursuit which could legitimately be perceived as a threat to the future of the shallower fisheries through the overexploitation that it was likely to generate. The powerful philhellenic feeling agitating on the islands, which was fuelled by the Cretan anti-Ottoman revolt, further explains the hostility of the sponge fishermen toward the companies linked by binding agreements with the Sublime Porte ${ }^{12}$.

\section{Decreeing a new use}

Concerned by the protection of their interests, foreign companies promptly mobilized their consular representations as well as the Ottoman governor on the island of Rhodes and claimed compensation and protection for their goods. However, their demands were met with nothing but rhetoric and delay. This procrastination on the part of the authorities did nothing to abate the violence. On the small island of Chalki on November 4 1866, the town council decided to confiscate all the stocks of the Coulombel and Devismes house, and in spring 1867, the population of Kalymnos again threatened Sakellarios, the representative of the Silvain Miles Co. , with death and forced him to put his renunciation of the hard-hat diving suit into writing. While the French company was finally granted compensation of 54,000 piastres by Constantinople, payment of the settlement met with opposition from the Kalymniots, to whom France answered by dispatching a war vessel to the island. The French vessel Forbin anchored twice in the port of Pothia and with the help of a Turkish vessel, forced the town council to 
compensate the French merchants and to revoke the prohibition of the hard-hat diving suit on the $4^{\text {th }}$ of May 1867. French military presence in the Dodecanese became very active in the following years, allowing the multiplication of these sponge harvesting "machines", and thus confirming this part of the Mediterranean, as well as the North African coast, as major investment sites for European companies. In 1868, Commodore Duperré estimated that 11 hardhat diving suits were operating on behalf of French companies in the archipelago, while two years later, 25 Kalymnian fishing boats with diving suits, belonging to the French Sponge Fishing Company, were harvesting sponges in the Gulf of Cyrenaic ${ }^{13}$.

Of course this new use did not lead to the immediate disappearance of the skin divers, who were actually able to continue their activity in Kalymnos until the end of the 1960s. However, the number of ships equipped with hard-hat diving suits did increase constantly on the island between 1866 and 1884 (Fig. 2). In 1898, Charles Flegel estimated that 350 "machines" were being used for sponge fishing, but he included divers in Florida in his statistics. The development of the hard hat diving suit explains the contraction of fishing fleets in harbours, with the appearance of bigger ships and an increasing number of crew members in the ports of the Dodecanese. As this scale of activity requires large amounts of capital, the labour organization and social relationships were also significantly affected ${ }^{14}$.

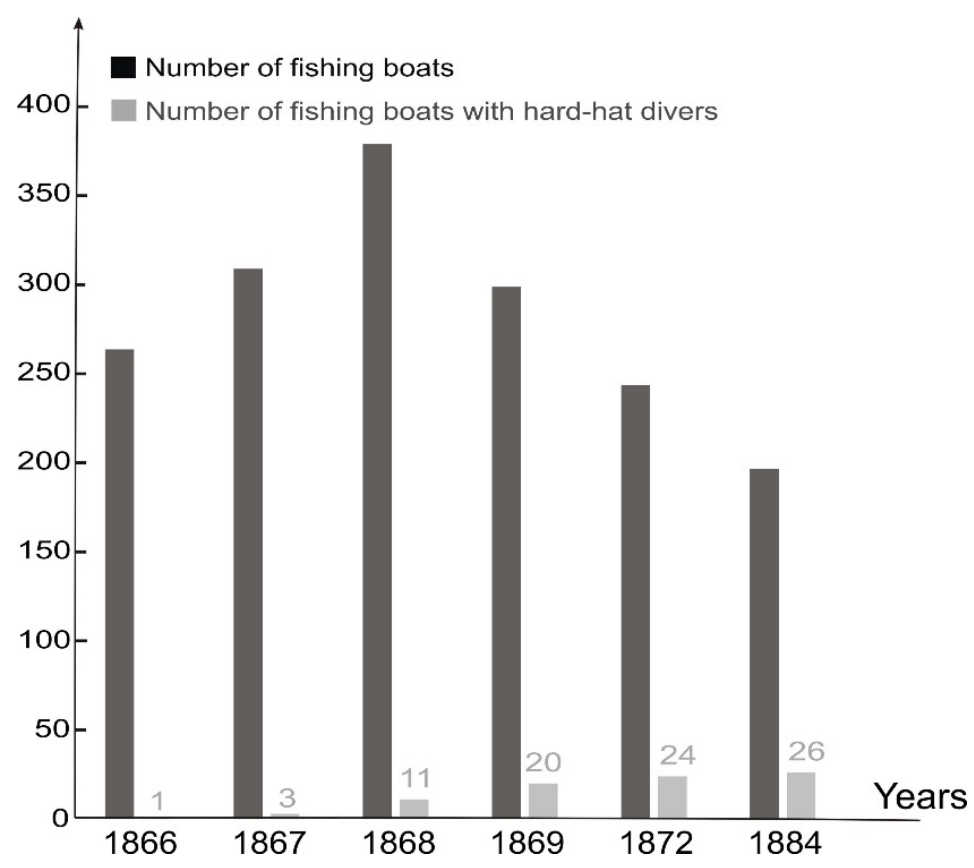

Figure 2: Evolution in time of the number of sponge fishing boats in Kalymnos (1866-1884) 


\section{II- Port communities partly transformed by the new technology}

\section{$\underline{\text { Modification of port areas }}$}

The intensification of the sponge fishery had visible consequences for the development of new port areas and led to a new distribution of island populations. The evolution of the small island of Kalymnos provides a good illustration. In 1830, Pothia was a haven on the island, with only sixty houses and warehouses. This number had doubled by 1895, in a context of high land speculation. In the port, construction of a large pier to further protect the ships was begun 1855 . The port basin itself was repeatedly deepened, and the decision to build docks was taken in 1902. By the end of the 19th century, the growth of commercial activities had forced the shipyard to move from the central part of the port basin to its north-west end. A $2.5 \%$ tax on the sale of sponges was collected by the town council and was used to finance schools and health works, but also covered the cost of major transformations of the port infrastructure during those decades ${ }^{15}$.

The population of Chora, which was at the time the main agglomeration of the island, migrated to Pothia from 1860 on as the new centre of activity was gradually reinforced by the development of shipbuilding activities, and the structuring activity of trading warehouses ${ }^{16}$.

\section{$\underline{\text { New funding and crew specialization }}$}

The arrival of the hard-hat diving suit in the Dodecanese Islands provoked two major changes in the organization of the fishing campaigns. The first arose from the amount of funding that had to be raised by the captains, which increased their dependence on ship-owners and sponge traders. The second concerned the methods of remuneration of the crews themselves, who became subject to a relatively new specialization in the domain of sponge fishing.

The new technology was expensive. Just before the Great War, the most frequent diving suit, the Denayrouze "type II", was listed at more than 3700 francs in the manufacturer's catalogue. Under these conditions, some of the Dodecanese captains had no choice but to put themselves in the service of the foreign companies who owned and were sometimes manufacturers of this diving gear. Such was the case for the "French Society of Sponge Fishing A. Denayrouze et Cie" which was based in Smyrna. Founded in 1865 by associate engineers Auguste Denayrouze and Benoît Rouquayrol, the Denayrouze Company aimed to integrate the scuba diving industry vertically, and was involved in everything from the manufacture of equipment to the international trade of sponges. Testimonies surrounding the aggression of the 
crew of a vessel working for this French company during the early days of July 1870 off the coast of Cyrenaica provide a good illustration of the financing systems of the vessels equipped with hard-hat diving suits. Under the leadership of artillery officer Louis Denayrouze, who was the brother of one of the founders of the company, 25 commercial divers were contracted by Dodecanese captains to harvest sponges in Libya during the summer of 1870. All the "machines" used by divers of the archipelago aboard these fishing vessels belonged to French manufacturer-traders. When fishing along the African coasts, the fishing vessels typically needed a depot ship. The Aghios Nicolaos, a schooner commanded by the Hydriot captain Dimitri, but owned by the Kalymniot Tsezellarios Karavokyros, was thus chartered by five captains working in Cyrenaica with the "machines" of the company Denayrouze. In addition to stocking the treated sponges, this schooner was equipped with 6 hard-hat diving suits perhaps kept in reserve, including one which belonged to another French house, "Guys and Co." based in Smyrne. While replenishing their water supplies near Marsa El Brega, the schooner was attacked by shepherds of the Mogharba nomadic tribe, resulting in the death of the captain and one of the sailors. This testimony gives some indication of the complexity of the financial arrangements implemented in the Dodecanese Islands, where hard-hat diving was mostly external to simple self-financing by captains (Fig. 3). The captains not only had to raise large sums of money before departure to pay part of the crews' salaries as well as the ship supplies and charter in advance, but they also became dependent on one or more of the foreign trade companies renting the diving gear ${ }^{17}$. 


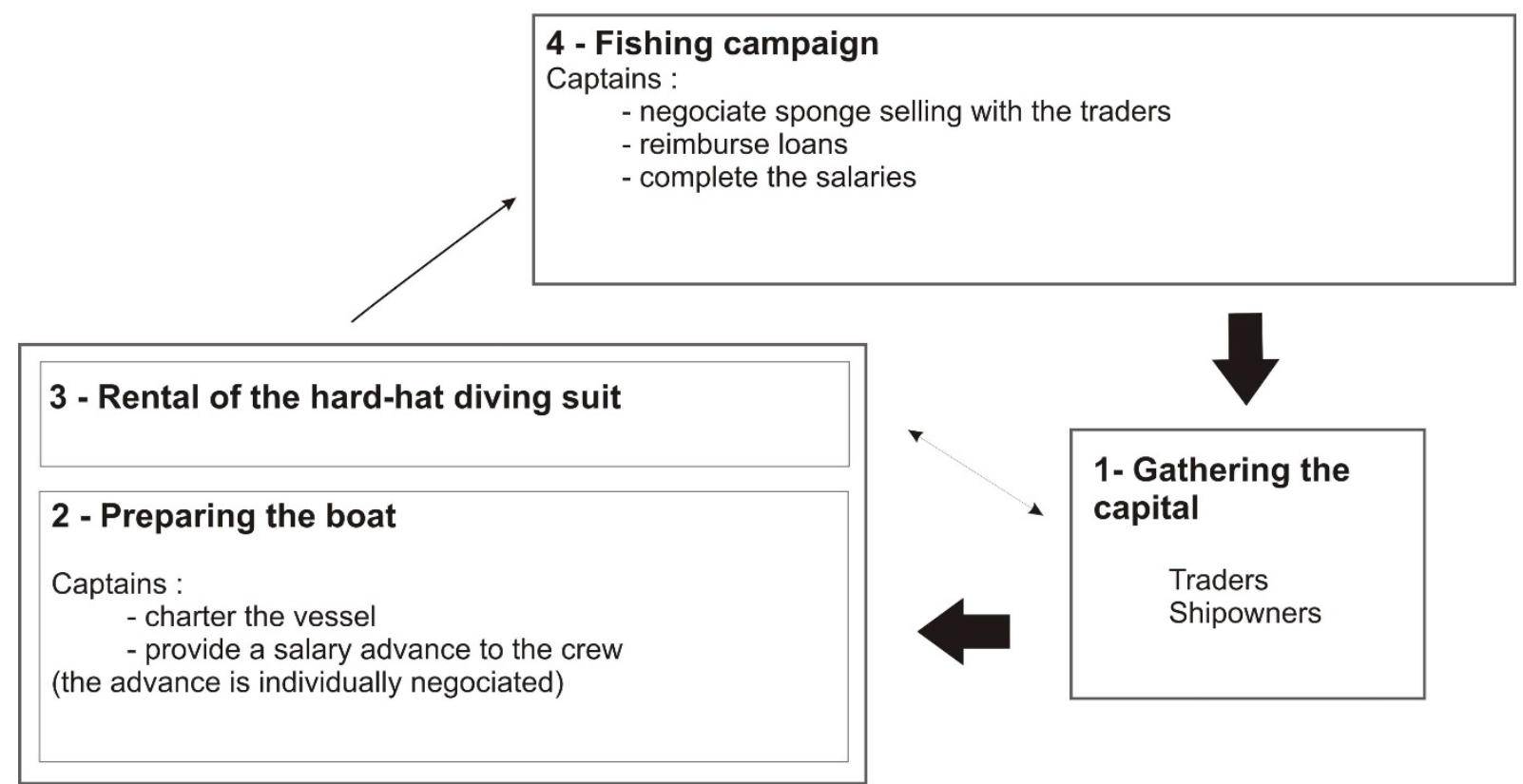

\section{Beginning of the campaing}

Figure 3: General organization of fishing campaigns using hard-hat diving

The mechanization of the sponge fishery both increased the captain's dependency and resulted in the destruction of the family organization that had prevailed in traditional fisheries. Prior to the introduction of the hard-hat diving suit, skin divers and trident harpoon (kamaki) fishermen generally funded their fishing season by teaming up or collaborating with a captain, who was also a diver or fisherman. The sale of the fishery product then allowed to attribute equal pay to the entire crew, with a share reserved for the maintenance of the boat. Disputes could obviously occur, for example, captains were sometimes accused of concealing part of the profits. However, the composition of the crews, which were often family-centred and always made up of small cohesive groups, most often ensured a climate of trust within the fishing vessels. $^{18}$

The introduction of the hard-hat diving suit overturned this traditional organization. The exorbitant investments required rendered the captains fully dependent on the traders and the ship-owners, who granted them loans at usurious rates of up to $24 \%$. The Dodecanese Islands experienced both the proletarianization of the workforce and a growing hierarchy within crews, which led to strong tensions aboard and the erosion of traditional solidarities. In early spring, contracts were drawn up after individual and secret negotiations between captains and crew members, including divers, which explains the great divergence of outcomes for each recruit. 
The difficulties caused locally by the harshness of this new organization created the need to implement new regulatory standards. A new regulation was proposed by the council of Kalymnos on March 1 1884, and can be seen as a draft preparation of a labour law. It regulated in particular the relationships between captains, divers, sailors and financers. Even if it fell short of creating an insurance fund as such, Article 24 of Part I stated that sailors and divers must receive the share expected at the time of outfitting, plus the profits from a good fishing event in the case of death during the fishing season. This salary advance was called "platika"19.

In general, however, the second half of the $19^{\text {th }}$ century was marked by growing economic difficulties among sponge fishermen. Divers and sailors were kept in constant debt as their financial insecurity often forced them to ask for advances of part or even all of their wages before departure. The captains, who were not always the owners of the vessel under their command, were insolvent debtors themselves who pushed for an abusive use of the hard-hat diving suit to pay off their own debts. In the context of increasingly dangerous fishing seasons, the mood was marked by the uncertainty of the future, and as a response to their desperate social instability, fishermen would spend a large part of the platika on festivities organized before their departure to sea.

\section{III- Implementation of new social legislation}

$\underline{\text { Port populations burned into their flesh }}$

The new fishing gear was not only responsible for transforming traditional social structures, but also caused a dramatic increase in mortality among fishermen. Sponge fishing, as practiced after 1860, was probably among the deadliest activities in the centuries-long history of the fishing economy. In 1912, Flegel recorded an annual mortality rate of 20\% amongst divers, while a further 25\% suffered serious trauma resulting in partial or total disability (Fig. 4). The same author estimated that 5500 deaths could be linked to the use of the "machine" since its introduction to the sponge fishery in 1866. These numbers are regularly cited by different authors, but must be handled with caution as they may have been exaggerated by the author. There is no doubt, however, that the fishing trips of those years had a very high human cost. The economist Sotiris Agapitidis estimated that before the First World War, 5 to 10\% of divers returning to Symi after each fishing season were either paralyzed or dead. Information from the Greek military authorities confirms these high percentages of accidents. Between 1903 
and 1905, the Greek navy ship "La Crete" was positioned off the Libyan coast with a hospital on board for the care of injured divers. The reports of its successive missions attest to the destructive character of the sponge diving campaigns. These records evoke the losses suffered by Greek fishermen in general, not only those of the Dodecanese, but in a single year, the navy vessel's captain Zotos recorded 26 deaths on the Greek sponge fishing boats. He was also informed of an additional 40 diver deaths on boats which did not contact his vessel directly. For the year 1903, he states that 100 accidents resulted in death or total paralysis among the 900 Greek divers operating in the waters of Libya and Tunisia. In 1881, in the context of this occupational health disaster, the hard-hat diving suit, "the machine", was qualified as "the divers’ minotaur" by the Symiot merchant Demosthenes Chaviaras ${ }^{20}$.

These scuba diving accidents, brought about by lack of knowledge concerning the physiological effects provoked by exposure to a hyperbaric medium, have mobilized researchers since the middle of the $19^{\text {th }}$ century. Despite being unable to define an effective therapeutic protocol, European physicians nevertheless specified the origin of the disease at the end of the 1860s, and their observations outlined the main pathologies related to nitrogen saturation of tissues. Starting in 1871, in the wake of the research by Alfred Leroy de Méricourt, many Greek physicians began to improve their knowledge of the bodily injury caused by the hard-hat. The successive publications by Epaminondas Kotsonopoulos, N. Lambadarios or Michel Catsaras provided the sponge trading companies with a scientific contribution that demonstrated the dangers of this tool for fishermen. In the last years of the $19^{\text {th }}$ century, medical expertise on diving accidents fuelled public debate and played a key role in the decision taken by some governments to ban the use of this fishing gear. This was the case in the Principality of Samos in 1897 and in Crete, where hard-hat diving was banned in 1899 by decision of the High Commissioner George of Greece ${ }^{21}$. 


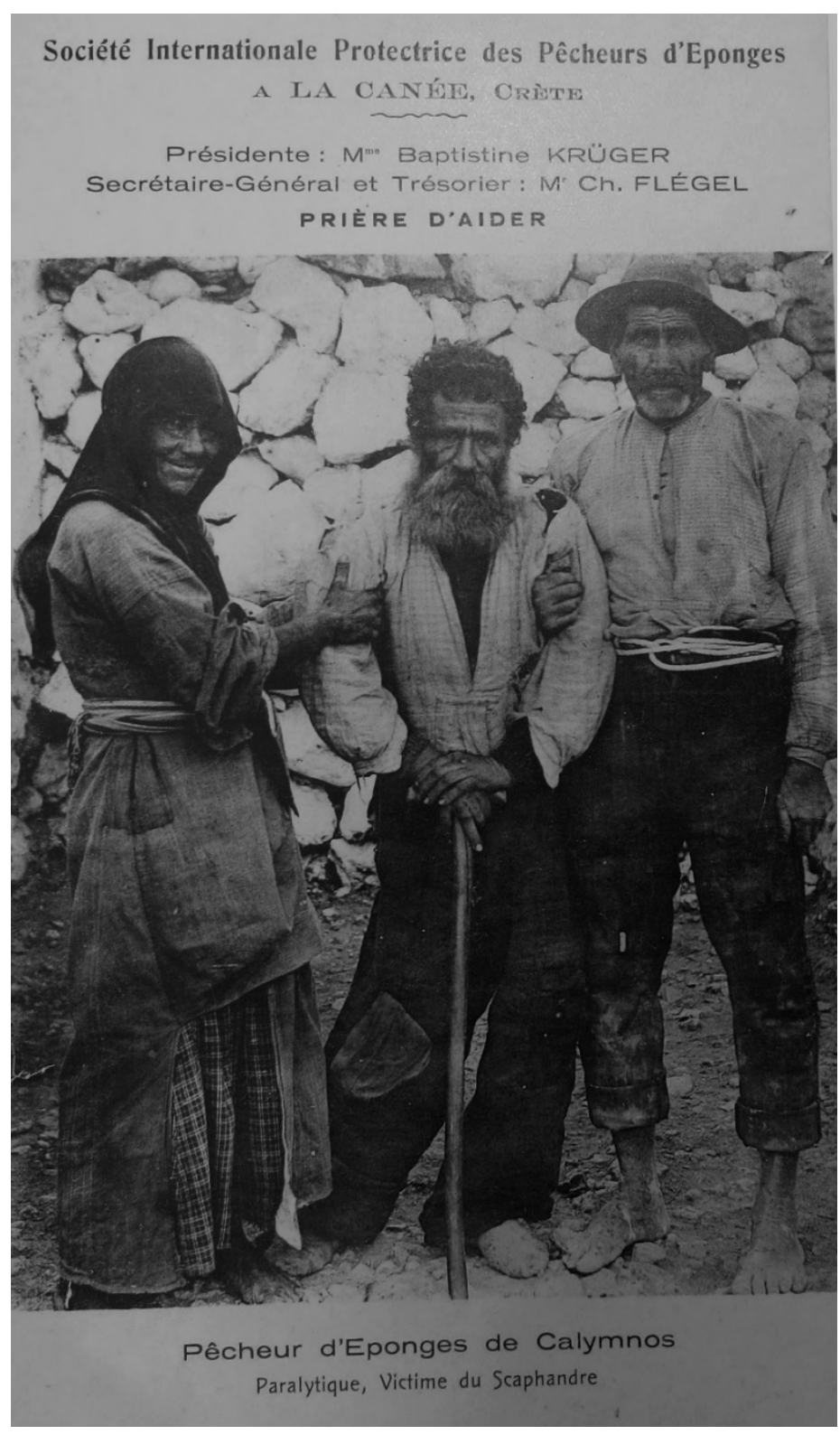

Figure 4: Card printed by the International Society for the Protection of Sponge Fishermen, 1911. Library of Monaco Oceanographic Museum, correspondence between Flegel and the Prince of Monaco.

\section{Charles Flegel (1850-1828): A port figure of philanthropy}

Flegel (Fig. 5) was a tireless supporter of the ban on the hard-hat diving suit at the turn of the century, and he multiplied reports, speeches and complaints against the suit. Born in 1850 in the Jewish community of Vilnius, Flegel is a central character in contemporary history 
of Mediterranean sponge fishing. Brother of the explorer Eduard Robert Flegel, who tragically disappeared in Africa in 1886. Flegel occupied a teaching position in the gymnasium of Rostov until 1888, before moving to Kalymnos in 1892 where he discovered the physical and moral misery of the sponge fishermen and decided to devote his life to improving the living conditions of these sea workers. He began to challenge state and local governments, with the publication of his first brochure on this theme in 1893, and participated in international congresses and world exhibitions. His proposals were formally examined at the Third, Fourth and Ninth International Congresses on Fishery and Fish Aquaculture held in St Petersburg (1902), Vienna (1903) and Washington (1908), respectively ${ }^{22}$.

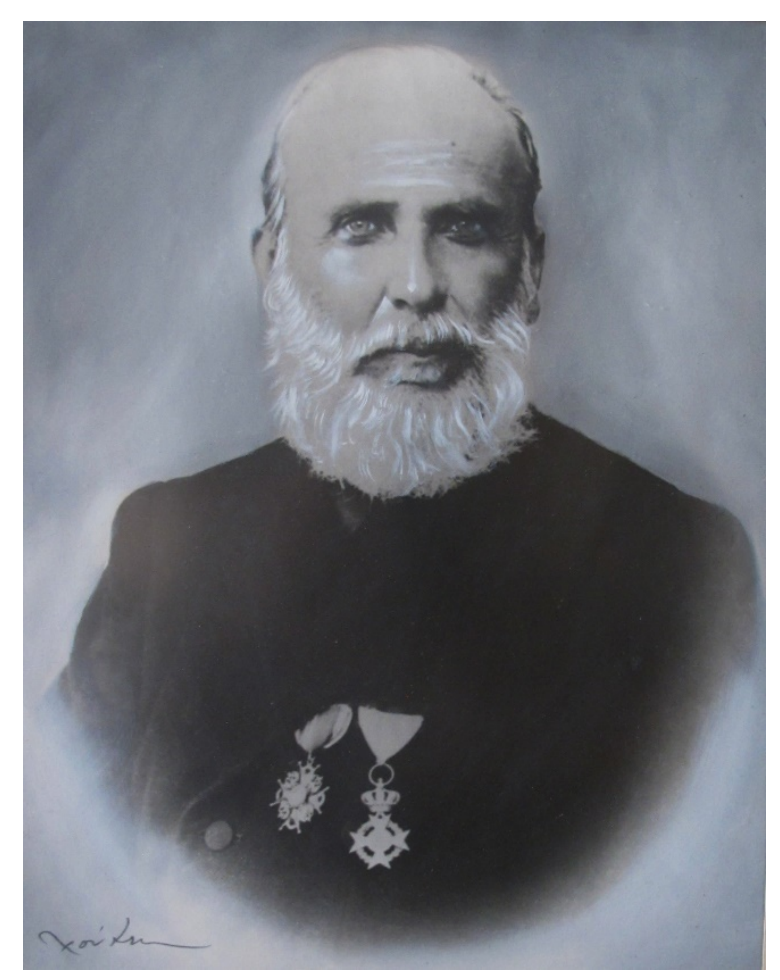

Figure 5: Charles Flegel (1850-1928). Kalymnos Library

It would be wrong to reduce Flegel's thinking to the simple goal of banning hard-hat diving from the fishing communities. His position, which he defended until his death, was born in the context of deep misery on Kalymnos in 1928, and his different publications reveal a more complex conviction. Indeed, Flegel's position was close to the reformist line defended by the International Congresses of Workers' Insurance, and he adhered to the current of mutualism which was sweeping the social democratic and Christian democratic movements that were developing in Western Europe at that time. He admired the ideas elaborated during the $7^{\text {th }}$ Congress of Vienna in 1905, and endorsed the words of the Austrian Minister Koerber: 
“Devant nos yeux brille le but commun d'appuyer le faible, quand il n'est plus capable de travailler ou quand il est sans travail, et de mettre ainsi la société humaine sur une base plus paisible et plus durable » (...Before our eyes shines the common goal of supporting the weak man when he is no longer able to work or when he is out of work, thus setting human society upon a more peaceful and sustainable foundation $)^{23}$.

By coupling the case of sponge fishermen with the definition of a legal norm characterizing work-related accidents, Flegel inevitably allied himself with the great union and philosophical debates of his time. Fundamentally pragmatic, he observed that long-term prohibition of the hard-hat diving suit was far from achieved. The ban had been respected in Crete since 1899, but was challenged or violated daily in many other countries that had gone through the motions of adopting it. An example of this occurred in Cyprus where the use of this gear was banned in 1901, but where diving licenses to Symiot crews were granted again as early as 1904.

If the termination of this practice remained the priority, its perpetuation required the implementation of schemes that would remediate the human damage it had caused. In 1911, the founding in Chania (Crete) of the "International Society for the Protection of Sponge Fishermen" responded to this need. In addition to the prohibition of the "machine", the latter set the objective of establishing a compensation and assistance fund for victims of accidents and their widows and orphans. A tax on sponge fishing licenses to finance this assistance fund began to take shape during the Italian conquest of the Dodecanese after $1911^{24}$.

\section{First draft of social legislation applied to sponge fishermen (1914-1922)}

The decree issued on March 81914 was the central government's first step toward taking the condition of sponge fishermen into account. Flegel backed the decree despite its numerous shortcomings: first of all, it concerned hard-hat divers only, and excluded all other sponge fishermen (e.g. skin divers or sailors). Moreover, its zone of application covered the Italian colonies of Cyrenaica and Tripolitania, reflecting the great potential of the North African sponge beds, while the "Possedimento" ports were not considered. Finally, the compensation system itself presented two major functional weaknesses: payments were made via the captains rather than from a general compensation fund, and compensation was organized according to the Greek tradition, which today appears archaic in the light of current Western European 
thought dealing with compensation for physical injury. In the case of death, the compensation paid amounted to 2000 lira, whereas victims suffering from permanent invalidity were paid only 1000 lira $^{25}$.

While other countries such as France in its Tunisian protectorate regulated the use of the hard-hat diving suit, the Italian decree of 1914 stands out from the other laws implemented in the Mediterranean by the particular attention it paid to the financial compensation of injured workers. The French regulation, which varied between prohibition and restricted use of the hard hat diving suit, was justified by its initiators by the ambition to protect the sponge resources from overexploitation. The health of the divers of the Gulf of Gabes was not covered by these regulations and drew the attention of Father Jean-Marie Raoul only, an ecclesiastic who developed submarines intended to remove the risk of accident. On the other hand, the Greek law of 1910 paid great attention to the prevention of accidents, precisely by establishing diving rules while setting up an accident fund nourished with compulsory contributions ${ }^{26}$.

A long period of paralysis occurred in the sponge fishing fleets during the First World War which can be explained by the fact that the legislation remained unchanged during the conflict. With the return of peace, new legal norms appeared in the territories controlled by Italy. Divers operating in Libya in 1920 were the first to experience the revision of the compensation indemnities, which rose (to 8000 lire) for the victims of permanent invalidity, thus surpassing payments for fatal accidents (4000 lire). In the Dodecanese Islands the new labour standards were transferred as early as December 1st 1921, first to the divers before being extended to all crew members by the decree of March 22nd 1922. This complementary ruling was signed by the Governor Regent of Rhodes, Alberto Albertazzi, and made way for the establishment of an Insurance Fund for the sponge fishermen of the Dodecanese, thus concretizing the wishes formulated by Flegel before the war. Contributions to this fund were obligatory and were proportional to the salaries of the crew members, and subscribing to this insurance was a prerequisite for the delivery of departure visas to the captains. In the case of an accident, the captain was required to file a detailed report which had been co-signed by two other crew members. This new rule guaranteed crew members that the basic safety measures would be respected aboard the sponge fishing vessel ${ }^{27}$.

The many records of injured divers found in the Italian archives in Rhodes show, however, that these successive texts actually had little effect in making diving safer over the next two decades. With hindsight this was to be expected, as these texts provided no article pertaining exclusively to the establishment of truly preventive measures. But even if these 
regulations in no way attenuated the misery inflicted by the "Minotaur" upon the Dodecanese, they did ensure the payment of limited subsidies to the bereaved survivors. The 4000 lira paid in cases of diver death in the mid-1930s was the equivalent of just two years' salary on average, which gives an indication of how little the authorities and traders of that period valued the life of sponge fishermen!

\footnotetext{
${ }^{1}$ Homer, The Odyssey, Song 1, verse 111

Oppien de Cilicie, Halieutiques, traduction de J.-M. Limes, Paris, 1817, chant V, 232-237.

George Sandys, A Relation of Journey Begun An. Dom. 1610: Foure books containing a description of the Turkish Empire, of Aegypt, of the Holy Land, of the Remote parts of Italy and Ilands adjoyning, London, 1673.

For the Dodecanese Archipelago: also named Southern Sporades, designates hereafter the twelve islands that had privileges concerning taxation and administration although under Ottoman control. These islands were: Astypalaia, Chalki, Ikaria, Kalymnos, Karpathos, Kasos, Kastellorizo, Leros, Nisyros, Patmos, Symi, Tilos. Later the Dodecanese became 15 main islands and were also named Possedimento by the Italians.

${ }^{2}$ Diplomatic Archives of Nantes (France), 116 PO 1 D 67-6, Ambassade de France à Constantinople. Correspondance avec les Échelles. Rhodes. «Rapport sur le commerce des éponges », by French Vice-Consul Rottier to Rhodes, 24 May 1838.

For the amount of water, see : Georges Vigarello, « Hygiène du corps et travail des apparences », Alain Corbin, Jean-Jacques Courtine, Georges Vigarello (dir.), Histoire du corps. T. II- De la Révolution à la Grande Guerre, Paris, 2005, 307.

${ }^{3}$ Departmental Archives of the Dodecanese in Rhodes, Series of the Italian-occupied period, 1916-1917, box 13, batch 19, Charles Flegel, « La pesca delle spugne e l'abuso dello scafandro », 3 November 1912, 2.

Departmental Archives of the Dodecanese in Rhodes, Series of the Italian-occupied period, 1929, box 105P, bacth 856, Georges Eleftheris Georgas, « Studio sulla pesca ed il commercio delle spugne, dal 1850 sino a oggi », 1926, 2 .

${ }^{4}$ Victor Langlois, «De la pêche des éponges et de leur commerce sur la côte de Syrie ", Revue de l'Orient de l'Algérie et des colonies. Bulletin et actes de la société orientale, algérienne et coloniale de France, Vol. 14, 1853, 249

Pierre Aublé, « Mémoire sur les éponges », 1867, 44-45, Library of Saint-Raphaël (France).

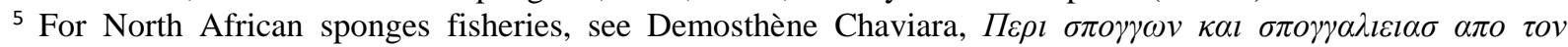

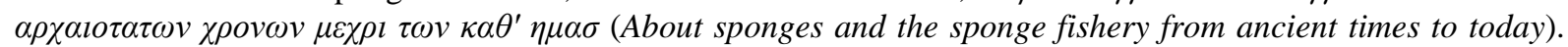
Athens, 1916, 36.

For 1854, see: Charles-Thomas Newton, Travels \& discoveries in the Levant. London, 1865, 293

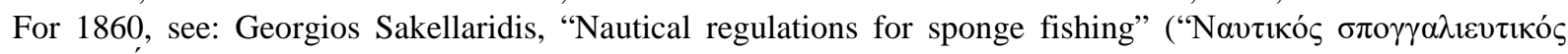
кavovioúos”). Kalymniaka chronika 24, 1994, 51.

Chaviara, idem, 40.

${ }^{6}$ For Siebe and Cabirol, see: Patrick Boulanger, Les « pieds-lourds marseillais », Marseille, n 223, 2008, 30-37.

For the introduction of the first «machine », see: Pierre Aublé, « Mémoire sur les éponges », 1867, Library of Saint-Raphaël (France), 53.

${ }^{7}$ For the diffusion of the machine, see: Departmental Archives of the Dodecanese in Rhodes, Series of the Italianoccupied period, 1929, box 105, batch 856, Georges Eleftheris Georgas, « Studio sulla pesca ed il commercio delle spugne, dal 1850 fino a oggi », 1926, 4.

${ }^{8}$ For the storm on $28^{\text {th }}$ August 1865, see: Archives of the Greek National Bank, "Report by Vice-Consul Biliotti on the Trade and Commerce of Rhodes, for the year 1865”. №181, 1866, Commercial Reports Received at the Foreign Office from Her Majesty's Consuls, 1866, London, 234.

For the carelessness of the captains, see: Demosthène Chaviara, About sponges and sponge fishermen from the


Athens, 1916, 50

${ }^{9}$ For the break-in into the trading house, see: Diplomatic Archives of Nantes (France), 116 PO 1 D 67-6, French Embassy in Constantinople. Letter from Zérounis to Mestrud, French Vice-Consul in Rhodes, 18 October 1865. For the destruction of the machine, see: Diplomatic Archives of Nantes (France), Letter from Zérounis to Mestrud, French Vice-Consul in Rhodes, 8 February 1866.
} 
${ }^{10}$ For the visit of the Ottoman governor: Idem., Letter from Mestrud, French Vice-Consul of Rhodes to the Marquis of Moustiers, French Ambassador in Constantinople, 6 November 1866.

For the destruction in Symi: Ibid, 14 November 1866.

${ }^{11}$ For the declaration made by the Kalymniots against the "machine": Ibid., 6 November 1866.

${ }^{12}$ For the declaration of Consul Biliotti about the traditional financiers, see: Archives of the Greek National Bank. Report by Vice-Consul Biliotti on the Trade and Commerce of Rhodes, for the year 1866. $\mathrm{N}^{\circ} 223,1867$, Commercial Reports Received at the Foreign Office from Her Majesty's Consuls, 1867. Part 1, London, 348.

For the declaration of Pierre Aublé, see: Pierre Aublé, 1867, « Mémoire sur les éponges », Library of SaintRaphaël (France), 19.

${ }^{13}$ For the confiscation of the strocks of the Coulombel \& Devismes house, see : Diplomatic Archives of Nantes (France), 116 PO 1 D 67-6, French Embassy in Constantinople. Letter from Coulombel to Mestrud, French ViceConsul in Rhodes, 8 November 1866.

For the threat upon Sakellarios, see: Idem, Letter of Mestrud, French Vice-Consul in Rhodes to Bourée, French Ambassador in Constantinople, 5 February 1867.

For the revocation of the prohibition of the hard-hat diving suit, see: History service of the French Navy, Toulon, 40 S 01. Fonds Forbin, Letter from Duperré, Commodore of the Forbin, to the Rear-Admiral Chief Commodore of the Navy in the Levant, 14 May 1867.

For the French military presence, see: Diplomatic Archives of Nantes (France), 166 PO D 98-6, French Embassy in Constantinople. Series D, Tripoli of Barbarie. Letter from L. Denayrouse, director of the French Company of Sponge Fishing, to E. Wiett, French Consul in Tripoli, 11 July 1870.

For the fishing boats in the Gulf of Cyrenaic in 1868, see : Idem, Letter from E. Wiett, French Consul in Tripoli, to Duke Gramont, French Minister of Foreign Affairs, 14 July 1870.

${ }^{14}$ For the presence of the skin divers until the end of the 1960s, see: Maïa Fourt, Daniel Faget, Thierry Pérez, « De la pierre au Fernez : coexistence et évolution des techniques de pêche des éponges commerciales en Méditerranée orientale durant l'entre-deux-guerres », Revue d'Histoire Maritime, 2018, nº 26.

For the statistics of the hard-hat diving suits, see: Departmental Archives of the Dodecanese, Series of Italianoccupied period, Box13, batch 1, 1917, Charles Flegel, « La pesca delle spugne e l’abuso dello scafandro », 1912, 4.

${ }^{15}$ For the increasing numbers of warehouses in Kalymnos, see: Kiriakos Chantzidakis, "H Ká $\left.\lambda v \mu v o \varsigma \sigma \tau \alpha \tau \varepsilon \dot{\lambda} \eta \tau\right\rceil \varsigma$ Тоиркократі́)" ("Kalymnos at the end of the Turkish domination") », Kalymniaka chronica, 7, 1989,79

For the construction of port infrastructures in Kalymnos, see: The Sporades. Report by the Vice-Consul Biliotti, on the Trade and Commerce of the Sporades for the year 1869, Commercial Reports Received at the Foreign Office from Her Majesty's Consuls, in 1869-70, London, 1871, 682

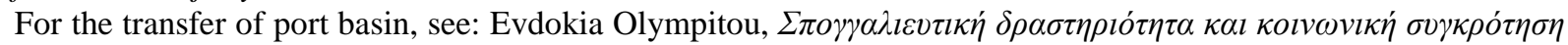

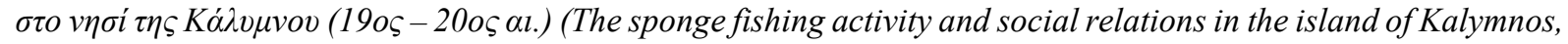
19th-20th century)., Athens, 2014, 61-62-63.

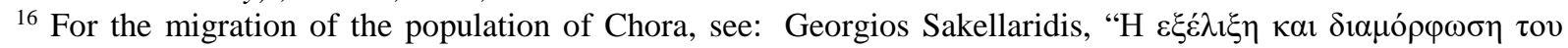
$\pi \lambda \eta \theta v \sigma \mu о v ์ \tau \eta s$ Kód $\lambda \nu \mu v o v$ " ("Development and evolution of the Kalymnos population”) Kalymniaka chronica, 8, 1990, 396

${ }^{17}$ For the price of the Denayrouze «Type II », see: Catalogue des prix courants des scaphandres Denayrouze, Société Charles Petit, 1915.

For the Denayrouze Company in 1870, see: Diplomatic Archives of Nantes (France), 166 PO /D98-6, French Embassy in Constantinople. Série D, Tripoli de Barbarie, letter from E. Wiett, French Consul in Tripoli, to Duke Gramont, French Minister of Foreign Affairs, 14 July 1870.

For the attack of Marsa El Brega, idem, Testimony of sailor YK, mariner on the Aghios Nicolaos, 11 July 1870.

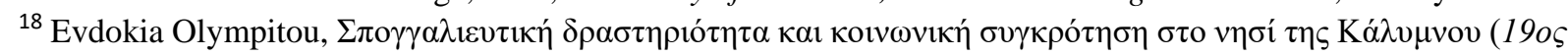
-20os $\alpha \mathrm{l}$.) (The sponge fishing activity and social relations in the island of Kalymnos, 19th-20th century). Athens, 2014,183.

For the accusation of misappropriation by the captains, see: Russel H. Bernard, "Sponge fishing and technological change in Greece", in H. R. Bernard and J. P. Pelto (ed.), Technology and social change, Illinois, vol. 111, 1972,171.

${ }^{19}$ For the evolution of the traditional organization of sponge fisheries, see: Evdokia Olympitou, The sponge fishing activity and social relations on the island of Kalymnos..., Athens, 2014,183.

For the usurious rates from the traders and ship-owners, see: Archives of the Greek National Bank. Commercial Report on Smyrna for the Year 1889. Part 1, 1890, in: Diplomatic and Consular Reports on Trade and Finance. Turkey. Report for the Year 1889 on the Trade of Smyrna. Harrison and Sons, London, 2-31.

${ }^{20}$ For the mortality rates, see: Departmental Archives of the Dodecanese, Series of Italian-occupied period, Box 13, batch 1, 1917, Charles Flegel, « La pesca delle spugne e l’abuso dello scafandro », 1912, 4. 
For the authors quoting these rates, see: Ioannis Polychronidis, C. Lyssimachou, G. Athanassenas G. (1994), " Diving Medicine in Greece during the 19th Century ", Proceedings of XXth Annual Meeting of EUBS, Istanbul, Turkey, Sept. 4-8, 1991, 1994, 15-20.

For the rates estimated by Sotiris Agapitidis, see: Sotiris Agapitidis, "The work in the sponge fishing activity".

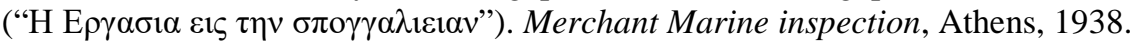

For the estimations from the Greek military authorities, see: P. Zotos, Report on the sponge fishing activity by

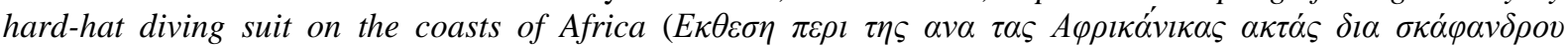

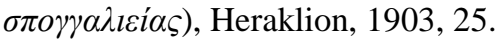

For the quote of Chaviaras, see: Departmental Archives of the Dodecanese, Series of Italian-occupied period, Box 12, batch 77-48, TM1/2, 1919-1922, rapport de Démosthène Chaviaras, 5 June 1921

${ }^{21}$ For the research by Alfred Leroy de Méricourt, see: Alfred Leroy de Méricourt, « Considérations sur l’hygiène des pêcheurs d'éponges », Annales d'Hygiène publique et de médecine légale, t.62, 1869, 279.

For the publications of E. Kotsonopoulos, see: E. Kotsonopoulos, « Case report of paraplegia on a diver working with hard-hat diving suit ", Asclepios 10, 1871, 65-76.

For the publications of N. Lampadarios, see: N. Lampadarios, « Accidents occurring in sponge divers », Asclepios 10, 1871, 161-179.

For the publications of Michel Catsaras, see: Michel Catsaras, « Recherches cliniques et expérimentales sur les accidents survenant par l'emploi des scaphandres », Archives de neurologie, t. XVI, 47, 1888, 145-194, (Clinique), t. XVI, 48, 1888, 346-395, (Clinique), t. XVII, 49, 1889, 22-84, (II, Clinique), t. XVII, 51, 1889, 329-432, (II, Clinique), t. XVIII, 52, 1889, 80-109, (III, Pathogénie), t. XVIII, 53, 1889, 207-243, (IV, Etiologie), t. XIX, 54, 1889, 48-77, (V-VII, Anatomie pathologique).

For the ban on the hard-hat diving suit, see: Charles Flegel, La question des pêcheurs d'éponges de la Méditerranée, La Canée, 1905, 37.

${ }^{21}$ For the decision of the High Commissioner George of Greece Idem, 34.

${ }^{22}$ For the situation of Charles Flegel before 1892, see: Charles Flegel, Lettre au président de la Société de géographie de Paris, 16 September 1904, BNF-Tolbiac, Société de géographie, Microfilm SG Colis 15 bis-2698. For the decision of Charles Flegel to defend the sponge fishermen, see: Charles Flegel, « L'Isola di Calymnos e la pesca delle spugne », Bolletino della società d'esplorazione commerciale del'Africa,1893.

Idem, L'Isola di Calymnos e la pesca delle spugne, Genova, 1895.

${ }^{23}$ For the International Congresses of Worker's Insurance, see: Isabelle Lespinet-Moret, « Les risques du métier. Des Congrès internationaux à l'Organisation internationale du travail, politique et représentation transnationale en matière d'accidents du travail (1889-1939) », Le Roux T., Risques industriels. Savoirs, régulations, politiques d'assistance (fin XVIII ${ }^{e}$ s. début XXe s.), Rennes, 2016, 117-133.

For the declaration of the Austrian Minister Koerber, see: Charles Flegel, La question des pêcheurs d'éponges de la Méditerranée, La Canée, 1905, 50.

${ }^{24}$ For Charles Flegel's request to allocate a financial compensation for the families, see: Departmental Archives of the Dodecanese, Series of Italian-occupied period, 1916-1917, box 13, batch 19, Charles Flegel, « La pesca delle spugne e l'abuso dello scafandro ", 3 November 1912, 8.

${ }^{25}$ For the Decree of 1914, see: Departmental Archives of the Dodecanese, Series of Italian-occupied period, 1922, box 98, batch 16, Decree of 8 March 1914 related to the injured hard-hat divers.

${ }^{26}$ For the French legislation, see: Eugène De Fages, Pêches maritimes de la Tunisie, Tunis, 1908, 256.

Décret beylical du 16 novembre 1902, suspendant l'application du décret du 4 août 1902 qui interdit l'emploi du scaphandre. Bulletin de la direction de l'agriculture et du commerce 5, 5.

Décret beylical du 18 juillet 1903 réglementant la pêche au scaphandre.

Décret beylical du 17 juillet 1906 réglementant la pêche des éponges sur toute l'étendue des bancs tunisiens.

For Father Jean-Marie Raoul, see: Patrick Martinenq, « Sous-marin pour la pêche aux éponges », Sillage, n² 2, March 1993.

De Fages, Pêches maritimes de la Tunisie, Tunis, 1908, 225-228.

For the Greek legislation, see: Decree in application of the 1910 law regulating the hard-hat diving suit for fishing purposes, Ministry of the Navy, 1912. Greek law $\Gamma X I Z$ ' governing fishing with the hard-hat diving suit. Document available at the Greek National Library (No $\left.\mu^{*} 2006 v\right)$

${ }^{27}$ For the first compensation indemnities, see: Departmental Archives of the Dodecanese, Series of Italian-occupied period, 1922, box 98 P, batch 16, letter from the Minister of the colonies to the Governor of Rhodes, 8 June 1921. ${ }^{27}$ For the extension of the law to the Dodecanese: Idem, Decree of 1 December 1921 on sponge fishing with hardhat diving suit in the Dodecanese waters.

${ }^{27}$ For the Decree of 1922, see: Departmental Archives of the Dodecanese, Series of Italian-occupied period, 19211923, Insurance fund and cases of diving accident, box 116 P, batch 19, decree of 29 March 1922. 